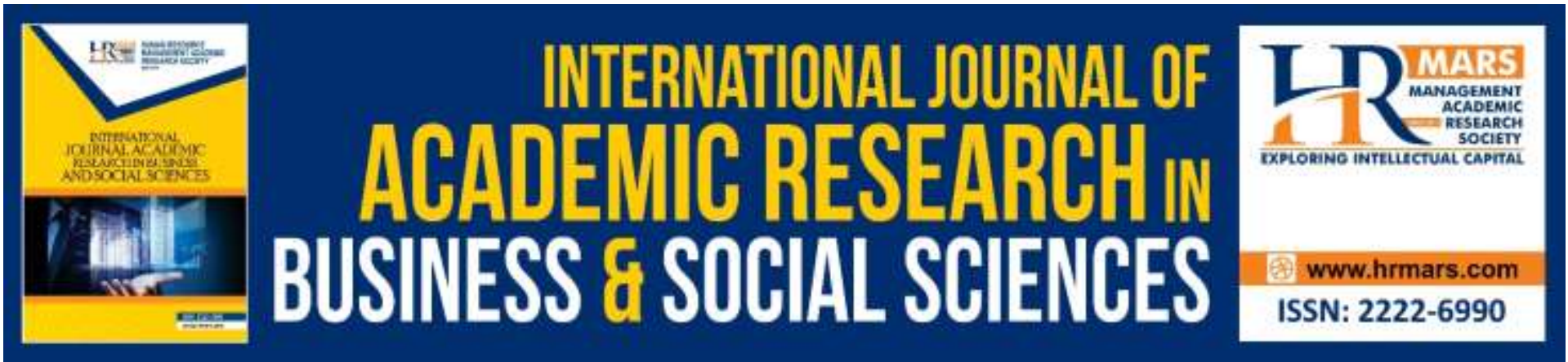

\title{
Revisting Indus Water Treaty
}

\section{Shahana Maryam, Mohamed Ali Bin Haniffa, Jazliza Binti Jamaluddin}

To Link this Article: http://dx.doi.org/10.6007/IJARBSS/v9-i10/6473

DOI: 10.6007/IJARBSS/v9-i10/6473

Received: 15 September 2019, Revised: 30 September 2019, Accepted: 10 October 2019

Published Online: 29 October 2019

In-Text Citation: (Maryam, Haniffa, \& Jamaluddin, 2019)

To Cite this Article: Maryam, S., Haniffa, M. A. B, \& Jamaluddin, J. B. (2019). Revisting Indus Water Treaty. International Journal of Academic Research in Business and Social Sciences, 9(10), 185-190.

\section{Copyright: (C) 2019 The Author(s)}

Published by Human Resource Management Academic Research Society (www.hrmars.com)

This article is published under the Creative Commons Attribution (CC BY 4.0) license. Anyone may reproduce, distribute, translate and create derivative works of this article (for both commercial and non-commercial purposes), subject to full attribution to the original publication and authors. The full terms of this license may be seen at: http://creativecommons.org/licences/by/4.0/legalcode

\section{Vol. 9, No. 10, 2019, Pg. 185 - 190}

Full Terms \& Conditions of access and use can be found at http://hrmars.com/index.php/pages/detail/publication-ethics 


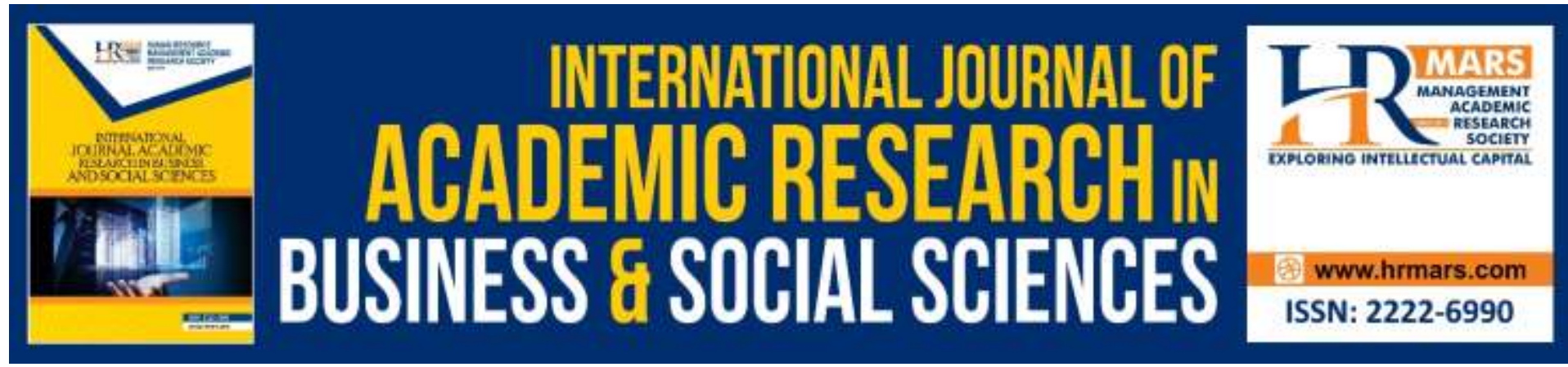

\title{
Revisting Indus Water Treaty
}

\author{
Shahana Maryam, Mohamed Ali bin Haniffa, Dr. Jazliza binti \\ Jamaluddin \\ University Utara Malaysia, Malaysia
}

\begin{abstract}
This conflict of access to water resources exaggerated with the growing political tussle of territorial hegemony. Thus the symbol of sovereignty for both newly built nations as independent nation-state after the end of British rule in 1947 was triggered with the access of water resources. The poor treatment of the partition and the vicious relocation of assets exacerbated the pressures between the two, prompting many years of contention. Moreover, the depicted limits set the phase for strains over water. The headwaters of the Indus were situated in Indian occupied Kashmir, and the lower bowl was in Pakistan. This set India at an undeniable favorable position, with the capacity to control the wellspring of water streaming into Pakistan. This investigation resulted into clash on water asset amongst Pakistan and India in the past and with evolving conditions, inspect the topographical stream of upstream - downstream water strife in regards to Indus Water Treaty definition, decide Indus water settlement understandings in light of the need for change, dissect the ramifications of Indus water arrangement utilizing systematic strategy procedure.
\end{abstract}

Keywords: Indus Basin, Dispute, Treaty, Pakistan, India.

\section{Introduction}

The fundamental resource of nature is water. The requirement of freshwater is required both normally and monetarily and it is also basic to wanders, for instance, fisheries, agriculture, mining, and amassing with conduits and these rivers provide $80 \%$ of the freshwater which have a basic needs of people. Two hundred and above rivers bowls on the planet that are starting at now shared by no less than two countries, circled across finished South America, North America, Africa, Europe and Asia covering about $47 \%$ of the earth's total landmass. (Elhance, 1999) The topic of research under discussion is water dispute arose due to Indus Basin between India and Pakistan. The aim of my research is to reassess and explore the various dimensions and content of the historical uprisings of the Indus Basin dispute from the perspective of regional geopolitics in Indus basin, including but not limiting to the process of international intervention and negotiation of dispute settlement by Indus Water Treaty of 1960. It invokes the turbulent relationship between upper and lower riparians by settling the answer of the 'ownership of water' in Indus Basin. The aftermath of partition intensified the hydro-politics of Indus Basin as new hierarchy of nationalist governments tried to persuade the landscape of Basin to reshape their economic and strategic interests. The Indus Basin comprises of 1,138,800 km2 zone, $14 \%$ exist in China, Nepal and Afghanistan rest $34 \%$ is in 
India remaining $52 \%$ lies in Pakistan. (Wolf, 2002) It was a continuous bone of contention for India and Pakistan as due to hustled phase of migration the boundary commission did not marked the water resources adequately resulting into a severe water conflict in the South East Asia. The waters of the Indus river systemi have never been a long way from the focal point of the Kashmir debate.

Indeed, even before autonomy for both nations came in 1947, the trustworthiness of the British-built water system works in the Punjab area was high on the rundown of variables, aside from religious lion's share, considered by Redcliffe in making his assurance of suitable limits at the season of Partition. On $1^{\text {st }}$ of April 1948, the Indian government discretionarily halted the stream of dilute the Sutlej River to Pakistan's West Punjab. This came at a basic point in the horticultural date-book and amidst expanded battling in Kashmir amongst Indian and Pakistani powers, extraordinarily fueling the post-Partition emergency in India-Pakistan relations. After more than a decade of political rivalry and exchange of harsh sentiments finally it was settled in 1960 by the mediation of World Bank as an agreement of settlement known as Indus Water Treaty for Indus Basin. The Treaty is interesting in this regard that it does not distribute the amount of accessible water between the riparian states rather it basically separates streams of the Indus framework. Eventually this settlement reduces the clashing requests of the states concerned moreover this division of the waterways of Indus Basin has limitized the complexity of political intermix that would have connected the rule of impartial distribution.

The valley of the river in its upper part is separated from the rest of Kashmir by very high mountains. The river Jhelum rises in Kashmir and enters Pakistan long before it emerges from the hills. The waters of these two rivers, which carry about two-third of the total flow of the entire Indus system, thus enters Pakistan as any large extraction of water is not possible from these resources. (PERHAM, 1952) The river Chenab raises in Punjab (India) and, after flowing through Himachal Pardesh (Polunin, 1984) and the Jammu Provinces of Kashmir, enters Pakistan soon after it emerges from the Himalayas. (Guha, 2000) Apart from two minor canals in Jammu, the entire waters of this river flow at present into Pakistan. The rivers Ravi and Sutlej pass at first through India and then through Pakistan; the river Beas lies wholly within

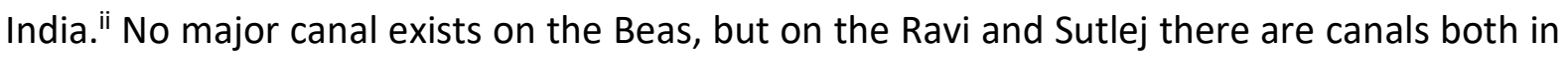
India and Pakistan. The western tributaries of the Indus lie in Afghanistan and Pakistan. On 4 May 1948, the marking of the Inter-Dominion (Delhi) Agreement get under way a prepare of occasions that drove in the long run to the 1960 IWT. (Z.Alam, 2002) These and different advancements through the span of the last 60 -odd years point to water's obvious nearness in the development of the Kashmir question.

\section{Discussion}

The whole of Pakistan depends on the Indus and its tributaries as a civilized and populous state. The Indus Water Treaty is extraordinary in that the division of waters among India and Pakistan isn't of waters in that capacity however the division of the waterways. Of these the western waterways the Indus, Jhelum and the Chenab have been selected for the utilization of Pakistan and the eastern streams Ravi, Beas and Sutlej intended for use by India. The Indus Treaty does not permit India to build storage dams on the rivers meant for Pakistan but allowed to make limited use for power generation. This would mean "run of the river schemes" which would still need some limited storage. The Baglihar project as well as two other projects, the Kishenganga and the Satle which have been objected to by Pakistan and 
seeking the World Bank Help for arbitration are all "run of the river schemes", fully justified in the treaty. The present study will base on Qualitative data and research strategies and devices for the study. The approach applied in this thesis towards the source material is a "Document Analysis". Both primary and secondary sources are deeply analyzed. There are many significant works which provide a wide knowledge on the subject. To conduct the research I have started from studying the secondary sources, i.e. books, journals, websites and thesis of master, master of philosophy and doctoral students. But, this study is mainly depended on the primary sources which has been available at the United Kingdom and Pakistan and institutes in Sargodha and other cities. For this purpose, the water management departments in Pakistan has the related source which dealt with problems related to the water resources at the time of partition and after it. A wide range of record for water dispute also reside with Indus Water Commission Lahore.

The Indus Treaty obviously sets out the method for settling question between the gatherings right off the bat the issue must be talked about reciprocally at the commission level-then go for an impartial master to look at the case to be named and later by the World Bank if both

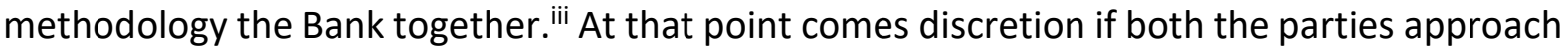
World Bank or if the issue isn't going towards any goals. Though it is implausible to expect that India could promptly and effectively disregard the terms of the Indus Water Treaty, Briscoe underscores keeping in view that Pakistan and India don't have "ordinary, trustful relations". The trust shortage alongside the way that India once blocked water streams to Pakistan has the military foundation persuaded that they should clutch their case to Kashmir with an end goal to keep up the nation's water security. (Wirsing, 2008)

The Indus Water Treaty has neglected to address two issues specifically the division of deficiencies in a very long dry weather among India and Pakistan and the total effect of storage of water on the Chenab River into Pakistan. The IWT obviously spreads out the standards for the utilization of surface water (counting mediation methods in case of contrasts or question), yet with regards to groundwater the board and administration, there is a major approach vacuum. In spite of the fact that the issue has been raised in different talks including arrangement and mainstream researchers of the two nations, no joint methodology has so far been embraced. Likewise, the settlement will in general negligence natural and climatic components, whose impacts on the Indus Basin are disentangling bit by bit.

The two India and Pakistan, being agrarian economies, are intensely reliant on horticulture. India and Pakistan are the first and fourth biggest clients of groundwater on the planet individually. 60 percent of India's watered territory is groundwater-commanded; and groundwater usage is very high in the conditions of Punjab, Haryana and Rajasthan - two of which share an outskirt with Pakistan. On the off chance that one takes the instance of the Punjab territory in Pakistan that produces 90 percent of the nation's nourishment, groundwater caters for in excess of 40 percent of the all out yield water prerequisites. The Punjab region of Pakistan imparts a fringe to both Punjab (Indian state) and Rajasthan.

\section{Conclusion}

Since the arrangement has withstood major and minor hiccups, the time has come to return to it and give driving force to it by putting inside its ambit issues, for example, groundwater just as natural and environmental change. The initial step ought to be to trade dependable 
and foresighted information on groundwater and not simply surface water. Be that as it may, participation ought not be restricted exclusively to the trading of information. Through political activities, the two nations should progress in the direction of an arrangement for coordinated bowl the board by actualizing groundwater revive projects and joint hydroelectric creation ventures - building a solid sub-territorial hydro-economy. This research paper contains entirely different approach from other researchers and historians of modern age like various research works on the literary perspectives on the climate change. Some focused on the biophysical human - environment, geography and cultural discourse. Some jumbled the various concepts of American neorealist approach along with pragmatism and rationalism concepts. The concept of hydro-hazardscape was theme of various researchers. However my research work is based on historical perspectives on the discourse of geopolitics of Indus Basin with political interests of South Asian States intersecting the natural geography of the region. Pakistan, being a vitality and water starved nation, would just profit by such activities. On the environmental change front, not exclusively can the opposite sides take part in joint specialized examinations on the effects of environmental change on the bowl, however they can likewise have joint activity plans for alleviation, adjustment and catastrophe hazard decrease. Since the Indus Basin involves India and Pakistan, yet additionally China and Afghanistan, there should be provincial coordination among all the four nations-albeit geopolitically this appears a long ways. Water is an existential issue and nations need to go past legislative issues to collaborate on Indus Basin the executives.

\section{References}

Elhance, A. P. (1999). Hydropolitics in the Third World: Conflict and cooperation in international river basins. Washington: US Institute of Peace Press.

Guha, R. (2000). The unquiet woods: ecological change and peasant resistance in the Himalaya. California: Univ of California Press.

Perham, J. C. (1952). Storm along Indus Hindu and Mos-lem Fight Over -Life-Giving Water. Barron's , p. 7.

Polunin, O. \&. (1984). Flowers of the Himalaya. New Delhi: Oxford University Press.

Wirsing, R. G. (2008). The Kashmir territorial dispute: the Indus runs through it. The Brown Journal of World Affairs , 225-240.

Wolf, A. T. (2002). Atlas of international freshwater agreements (Vol. 4. Chicago: UNEP/Earthprint.

Zalam, U. (2002). Questioning the water wars rationale: a case study of the Indus Waters Treaty. Geographical Journal , 341-353.

\footnotetext{
i The Indus river system consists of seven majodes the Indus itself, these are the Jhelum, Chenab, Ravi, Sutlej, Beas, and (flowing from the west) the Kabul.
}

Indus Basin Project, FCO 11/54, The National Archives, United Kingdom, 1967, pp. 3. i

"Agreement on Indus River System", The New York Times, 25 September 1960, pp.6 $6^{\mathrm{iii}}$ 